\title{
HUBUNGAN PERAN PENYULUH PERIKANAN DAN KEMAMPUAN AKSES MEDIA INFORMASI PEMBUDIDAYA IKAN TERHADAP PERKEMBANGAN PROGRAM MINAPOLITAN DI KECAMATAN CISEENG BOGOR
}

\author{
Oleh \\ Ina Restuwati \\ Dosen Jurusan Penyuluhan Perikanan Sekolah Tinggi Perikanan
}

\begin{abstract}
ABSTRAK
Penelitian mengenai hubungan peran penyuluh dan kemampuan mengakses media informasi pembudidaya ikan terhadap perkembangan program minapolitan di Kecamatan Ciseeng Kabupaten Bogor dilakukan untuk menganalisis hubungan peran penyuluh dan karakteristik pembudidaya ikan dalam mengakses media informasi serta pengaruhnya terhadap perkembangan program minapolitan. Responden ditentukan secara acak sederhana (simple random sampling). Data ditabulasi dan dilakukan pengkategorian, kemudian dilakukan analisis hubungan dengan mempergunakan Uji Pearson Chi Square. Hasil penelitian menunjukkan bahwa mayoritas pembudidaya ikan sering mengakses media dan sumber informasi.

Dari analisis jejaring komunikasi pembudidaya dalam satu periode pemeliharaan menunjukkan bahwa komunikasi dengan penyuluh perikanan ratarata dua kali. Keempat peran penyuluh perikanan berkorelasi sangat kuat terhadap peningkatan jumlah produksi dan peningkatan kemampuan teknis pembudidaya ikan lele dalam mendukung perkembangan program bantuan minapolitan. Analisis uji Pearson Chi Square menunjukkan bahwa karakteristik pembudidaya dalam mengakses media dan sumber informasi berhubungan nyata. Sedangkan dari analisis karakteristik jejaring komunikasi kelompok menunjukkan bahwa peran penyuluh perikanan berkaitan erat dengan tingkat perkembangan program bantuan minapolitan di Kecamatan Ciseeng Kabupaten Bogor. Hasil penelitian ini menunjukkan bahwa peran penyuluh dan kemampuan pembudidaya ikan dalam mengakses informasi berpengaruh terhadap perkembangan program minapolitan di kawasan ini.
\end{abstract}

Kata Kunci: pembudidaya, minapolitan, akses informasi, peran penyuluh

\begin{tabular}{crlr}
\multicolumn{2}{c}{ PENDAHULUAN } & nasional yang ditetapkan oleh \\
Program & minapolitan & Kementerian Kelautan dan Perikanan \\
merupakan salah satu kebijakan & dalam rangka percepatan
\end{tabular}


pembangunan sektor kelautan dan perikanan. Program minapolitan dimulai pada tahun 2009 melalui Surat Keputusan Menteri Kelautan dan Perikanan Nomor 41/MEN/2009 tentang Penetapan Lokasi Minapolitan dan Surat Keputusan Direktur Jenderal Perikanan Budidaya Nomor KEP.45/DJ$\mathrm{PB} / 2009$, tentang Pedoman Umum Pengembangan Minapolitan. Pengembangan lebih lanjut ditegaskan kembali melalui Surat Keputusan Menteri Kelautan dan Perikanan Nomor 12/MEN/2010 tentang minapolitan, Keputusan Menteri Kelautan dan Perikanan No.18/MEN/2011 tentang pedoman pelaksanaan minapolitan serta Keputusan Menteri Kelautan dan Perikanan No.39/MEN/2011 yang merupakan perubahan dari Kepmen No.32/MEN/2010 tentang penetapan kawasan minapolitan di seluruh Indonesia.

Konsep minapolitan didasarkan pada tiga asas, yaitu 1) demokratisasi ekonomi kelautan dan perikanan pro rakyat, 2) keberpihakan pemerintah pada rakyat kecil melalui pemberdayaan masyarakat, dan 3) penguatan peran ekonomi daerah dengan prinsip daerah kuat bangsa dan negara kuat. Ketiga prinsip tersebut menjadi landasan perumusan kebijakan dan kegiatan pembangunan sektor kelautan dan perikanan agar pemanfaatan sumberdaya kelautan dan perikanan benar-benar untuk kesejahteraan rakyat dan menempatkan daerah pada posisi sentral dalam pembangunan. Dengan konsep minapolitan diharapkan pembangunan sektor kelautan dan perikanan dapat dilaksanakan secara terintegrasi, efisien, berkualitas, dan berakselerasi tinggi.

Kabupaten Bogor merupakan salah satu dari seratus sembilan puluh tujuh kabupaten/kota yang ditetapkan menjadi kawasan minapolitan oleh Kementerian Kelautan dan Perikanan. Program ini sejalan dengan visi dan misi Bupati Bogor untuk merevitalisasi perikanan dengan komoditas unggulan ikan lele. Kecamatan Ciseeng merupakan salah satu kawasan minapolitan dikarenakan memiliki budidaya ikan lele yang tersebar di sepuluh desanya yaitu Desa Babakan, Putatnutug, Cibeuteung Udik, Cibeuteung Muara, Parigi Mekar, Ciseeng, Cihowe, Cibentang, Karihkil dan Kuripan. Kegiatan usaha yang dilakukan mayoritas pembenihan ikan lele dengan alasan biaya yang dikeluarkan lebih sedikit dibandingkan pembesaran serta mudah untuk dipasarkan baik lokal maupun antar pulau.

Sophia (1988) berpendapat bahwa selain komunikasi melalui media cetak seperti artikel, majalah, buku, laporan teknis, buletin dan sebagainya, pesan atau informasi dapat disampaikan juga melalui saluran yang bersifat lisan seperti : pembicaraan tatap muka, melalui interaktif radio, melalui televisi, korespondensi perorangan, seminar, pertemuan ilmiah dan sebagainya. 
Akan tetapi suatu informasi dapat pula diperoleh melalui media telekomunikasi yang melakukan pembicaraan tidak melalui tatap muka, seperti melalui telepon, handphone dan internet.

$$
\text { McQuail D. }
$$

berpendapat bahwa media massa akan efektif sampai di khalayak apabila : (a) melaporkan dan menginformasikan secara efektif, (b) memperluas cakrawala, dan (c) menciptakan iklim untuk membangun. Dalam proses pengambilan keputusan media massa dapat merubah perilaku atau nilainilai yang bersifat praktis dan cepat.

Dengan demikian akses media dan sumber informasi merupakan bagian yang tak terpisahkan dalam peningkatan kapasitas pembudidaya terutama dalam mengakses berbagai informasi mengenai teknis budidaya, pemasaran maupun manajemen pengelolaan usaha budidaya. Akses media berupa elektronik merupakan pilihan pembudidaya untuk mengakses informasi-informasi tentang budidaya perikanan selain media sumber informasi lainnya seperti surat kabar, majalah perikanan, bulletin dan sejenisnya yang berhubungan langsung dengan teknis produksi budidaya. Akses media dan sumber informasi diduga berhubungan dengan indikator perkembangan bantuan minapolitan dalam hal peningkatan kemampuan teknis pembudidaya, minat usaha berbudidaya ikan lele, serta wawasan tentang pemasaran hasil budidaya.

\section{Rumusan Masalah}

Perumusan masalah penelitian ini adalah :

1. Apakah terdapat hubungan antara karakteristik individu dalam mengakses media informasi dan Peran Penyuluh perikanan terhadap keberhasilan program bantuan minapolitan di Kecamatan Ciseeng.

2. Bagaimanakah keterkaitan antara karakteristik individu pembudidaya ikan dalam mengakses media dan sumber informasi serta peran penyuluh perikanan terhadap perkembangan program minapolitan.

\section{Tujuan Penelitian}

Tujuan penelitian adalah :
1. Menganalisis hubungan karakteristik individu pembudidaya ikan dalam mengakses media dan sumber informasi serta Peran Penyuluh Perikanan terhadap keberhasilan program minapolitan di Kecamatan Ciseeng.

2. Menganalisis keterkaitan antara karakteristik individu pembudidaya ikan dalam mengakses media dan sumber informasi serta peran penyuluh perikanan terhadap perkembangan program minapolitan di Kecamatan Ciseeng.

\section{Manfaat Penelitian}

Penelitian ini diharapkan dapat bermanfaat untuk :

1. Memberikan kontribusi terhadap penelitian serupa tentang 
pentingnya akses media dan sumber informasi bagi pembudidaya ikan

2. Menjadi pertimbangan bagi pemerintah daerah maupun pusat dalam mengembangkan kawasan minapolitan dan merencanakan strategi pengembangan lebih lanjut

3. Meningkatkan motivasi pembudidaya sebagai produsen ikan lele di Kecamatan Ciseeng melalui kemampuan dalam mengakses media informasi

\section{Kerangka Berfikir dan Hipotesis}

Perumusan hipotesis dari penelitian ini adalah :

$\begin{array}{rlr}\text { H0 } & \text { Karakteristik } & \text { individu } \\ & \text { pembudidaya ikan } & \text { dalam } \\ & \text { mengakses media } & \text { informasi } \\ & \text { dan Peran Penyuluh Perikanan } \\ \text { di Kecamatan } & \text { Ciseeng } \\ & \text { berhubungan nyata } & \text { dengan } \\ & \text { Perkembangan } & \text { program } \\ & \text { minapolitan. } & \\ \text { H1 } & \text { Karakteristik } & \text { individu } \\ & \text { pembudidaya ikan } & \text { dalam } \\ & \text { mengakses media informasi } \\ & \text { dan Peran Penyuluh Perikanan } \\ & \text { di Kecamatan Ciseeng tidak } \\ & \text { berhubungan nyata } & \text { dengan } \\ & \text { Perkembangan } & \text { program } \\ & \text { minapolitan. }\end{array}$

Berdasarkan kerangka pemikiran di atas diharapkan dapat menjawab adanya hubungan karakteristik individu pembudidaya ikan dalam mengakses media dan informasi serta peran penyuluh terhadap perkembangan program minapolitan di Kecamatan Ciseeng Kabupaten Bogor. Variabel-variabel yang akan diteliti meliputi aspek karakteristik individu pembudidaya dalam mengakses media dan sumber informasi serta peran penyuluh perikanan.

\section{METODOLOGI PENELITIAN}

Penelitian ini adalah rancangan yang bersifat deskriptif korelasional tentang hubungan karakteristik individu pembudidaya ikan lele dalam mengakses media dan sumber informasi serta peran penyuluh perikanan terhadap indikator perkembangan program bantuan minapolitan di Kecamatan Ciseeng Kabupaten Bogor. Pemilihan daerah penelitian dilakukan secara sengaja (purposive) dengan alasan bahwa Kecamatan Ciseeng adalah salah satu kecamatan di wilayah Bogor yang ditetapkan sebagai salah satu kawasan minapolitan untuk pengembangan komoditas ikan lele. Hal ini merujuk kepada pendapat bahwa pengambilan sampel yang tidak berdasarkan random, daerah atau strata, melainkan berdasarkan atas adanya pertimbangan yang berfokus pada tujuan tertentu, (Arikunto, 2006).

\section{Populasi dan Sampel}

Populasi dalam penelitian ini adalah 40 kelompok pembudidaya dengan anggotanya sebanyak lebih kurang 400 orang yang tercatat masih aktif melakukan kegiatan budidaya dengan tingkatan dan kelas 
kelompok yang beragam, dan responden adalah anggota kelompok. Responden diambil secara acak sederhana (simple random sampling) yaitu suatu metode pemilihan sampel dimana setiap anggota populasi mempunyai peluang yang sama untuk dipilih (Umar, 2001). Sampel yang diambil sebanyak 10 kelompok (25\%), Masing-masing kelompok diambil sebanyak 5 orang sehingga jumlah keseluruhan sampel sebanyak 50 orang.

\section{Waktu dan Tempat Penelitian}

Penelitian ini dilaksanakan dari bulan Februari sampai dengan April 2012, di kawasan minapolitan Kecamatan Ciseeng Kabupaten Bogor.

\section{Metode Analisis Data}

Berdasarkan tujuan penelitian, model teoritis yang dikembangkan serta hipotesis yang diajukan, maka untuk keperluan deskripsi penelitian dipergunakan interpretasi data dari masing-masing variabel yang diuji. Dengan demikian penelitian ini mempergunakan beberapa analisis yaitu :

a. Analisis Pearson Chi Square, untuk melihat hubungan antara karakteristik individu pembudidaya dalam mengakses media informasi dan peran penyuluh perikanan dengan kriteria indikator perkembangan bantuan minapolitan di kawasan minapolitan Kecamatan Ciseeng dengan taraf kepercayaan 5\% atau $\alpha$ 0,05. Rumus Pearson ChiSquare yang digunakan untuk menguji hipotesis komparatif lebih dari dua sampel bila datanya berbentuk diskrit atau nominal, (Sugiyono, 2004) sebagai berikut

$$
\chi^{2}=\Sigma \frac{(Q-E)^{2}}{E}
$$

Keterangan :

$\chi^{2} \quad$ : Koefisien Chi

Square

O : Frekuensi

pengamatan

E : Frekuensi harapan

b. Perhitungan uji statistik pada penelitian ini mempergunakan program SPSS, dengan merujuk kepada pendapat (Santoso. et al 2001) bahwa untuk regresi dengan lebih dari dua variabel independen digunakan Adjusted R 2 sebagai koefisien determinasi. Variabel yang dianalisa dengan metode ini adalah variabel yang bersifat kualitatif, yaitu yang memiliki skala nominal. Dengan kata lain tabulasi silang merupakan salah satu alat yang paling berguna untuk mempelajari hubungan diantara variabel-variabel karena hasilnya mudah dikomunikasikan.

\section{HASIL DAN PEMBAHASAN}

Kecamatan Ciseeng merupakan salah satu sentra pengembangan pembenihan yang mempunyai potensi pengembangan yang luar biasa, mengingat jumlah pembudidaya sebagai produsen ikan lele yang melakukan proses pembenihan ikan lele maupun pembesaran jumlahnya 
cukup banyak untuk memenuhi permintaan benih ikan lele baik di dalam Kecamatan Ciseeng sendiri, di luar kecamatan, maupun daerah Bogor lainnya. Menurut data Dinas Peternakan dan Perikanan Kabupaten Bogor tahun 2010, secara umum total luas lahan usaha pembenihan ikan di Kabupaten Bogor adalah 693,221 ha, dan menyerap tenaga kerja sebanyak 1.569 RTP dengan jumlah produksi tahun 2010 sebanyak 920.352.390 ekor, yang tersebar hampir di seluruh wilayah kecamatan, namun yang merupakan sentra pembenihan ditinjau dari luas lahan maupun RTP (Rumah Tangga Perikanan) terdapat di Kecamatan Ciseeng, Parung, Pamijahan dan Cibungbulang dengan jenis ikan yang dibenihkan mayoritas komoditi ikan Lele, Mas dan bawal

Melihat potensi ini, maka Kecamatan Ciseeng merupakan salah satu kecamatan di Kabupaten Bogor yang ditetapkan sebagai kawasan minapolitan berbasis perikanan budidaya dengan komoditas ikan lele sebagai unggulannya. Melalui surat keputusan Menteri Kelautan dan Perikanan (Kepmen KP) Nomor: 32/MEN/2010 ini telah ditetapkan 197 kabupaten/kota dari 33 propinsi yang ada di Indonesia sebagai kawasan minapolitan. Program pendukung minapolitan yang diluncurkan adalah Pengembangan Usaha Mina Pedesaan (PUMP) yang bertujuan untuk meningkatkan produksi, menumbuhkan wirausaha dan meningkatkan kesejahteraan masyarakat kelautan dan perikanan di pedesaan. Khusus PUMP berbasis perikanan budidaya dilaksanakan untuk 300 kabupaten/kota dimana salah satunya dilaksanakan di Kabupaten Bogor tepatnya di Kecamatan Ciseeng sebagai salah satu kawasan minapolitan. Kelompok pembudidaya yang berada di Kecamatan Ciseeng merupakan para pelaku usaha yang memegang peranan penting untuk keberhasilan program minapolitan di kawasan ini. Dibawah ini akan dikemukakan hasil distribusi pembudidaya berdasarkan karakteristik individu dalam mengakses media dan sumber informasi serta peran penyuluh perikanan di dalamnya.

Distribusi Pembudidaya

Berdasarkan Akses Media dan Sumber Informasi

Susanto-Sunario, S. Astrid (1993), dalam bukunya berpendapat, argumentasi media massa diperlukan oleh masyarakat karena manusia memerlukan berbagai informasi sebelum ia menuju ke tempat kerjanya dengan slogan "surat kabar di samping cangkir kopi di pagi hari". Eksklusivisme surat kabar ini cepat disaingi oleh radio dan televisi, sehingga dapat dikatakan bahwa yang lebih akrab dengan masyarakat kecil adalah kedua media yang bersifat audial/ visual audial. Karena pembelian surat kabar menginginkan penyisihan sejumlah dana setiap hari ataupun pada awal bulan, maka segera dapat diketahui bahwa pembaca surat kabar adalah orang yang kemampuan ekonominya jelas sudah di atas garis kemiskinan. Dengan demikian jelaslah bahwa 
terdapat perbedaan pengaruh surat kabar di masyarakat dibandingkan dengan media radio dan televisi.

Merujuk kepada pendapat tersebut, akses media dan sumber informasi yang dimaksudkan dalam penelitian ini adalah seberapa sering pembudidaya mengakses media dan sumber informasi lainnya baik melalui media cetak seperti koran, majalah, buletin serta media elektronik seperti televisi, radio dan internet. Hasil penelitian mengenai distribusi pembudidaya berdasarkan akses media dan sumber informasi tersaji dalam tabel 1 seperti berikut ini :

Tabel 1. Distribusi Pembudidaya Berdasarkan Akses Media dan Informasi

\begin{tabular}{|c|c|c|}
\hline Frekuensi (kali) & Jumlah & Persentase \\
\hline Jarang $(<2)$ & 15 & 30 \\
\hline Kadang-kadang (2-4) & 17 & 34 \\
\hline Sering $(>5)$ & 18 & 36 \\
\hline \multicolumn{2}{|c|}{50} & \\
\hline Kumber : Hasil penelitian Tahun 2012 & \\
Keterangan : - Frekuensi minimum 1 kali & Frekuensi maksimum 6 kali \\
$-\quad$ Rata-rata 3 kali
\end{tabular}

Tabel 1 menunjukkan bahwa hasil penelitian dari 50 responden pembudidaya, mayoritas pembudidaya responden sering mengakses media dan sumber informasi yaitu sebesar 36 persen atau sebanyak 18 orang, keadaan ini cukup berimbang dengan pembudidaya yang jarang maupun kadang-kadang mengakses informasi.

\section{Distribusi Pembudidaya Melakukan Interaksi Komunikasi Dengan Penyuluh Perikanan}

Van Den Ban dan Hawkins (1999), menyatakan bahwa penyuluhan merupakan keterlibatan seseorang untuk melakukan komunikasi informasi secara sadar dengan tujuan membantu sesama memberikan pendapat sehingga dapat membuat keputusan yang benar. Berdasarkan pendapat ini maka diperlukan interaksi komunikasi antara pembudidaya ikan dengan penyu;uh perikanan.

Interaksi komunikasi dengan penyuluh perikanan dalam penelitian ini adalah banyaknya intensitas komunikasi antara pembudidaya ikan dengan penyuluh perikanan setempat. Interaksi ini dibagi ke dalam tiga kategori yaitu rendah dengan frekuensi 1 kali setiap periode budidaya berlangsung, kategori sedang dengan frekuensi 2 kali dan kategori tinggi dengan frekuensi berinteraksi sebanyak lebih dari 3 kali. Hasil penelitian tentang distribusi penyuluh berdasarkan interaksi dengan penyuluh perikanan disajikan dalam tabel 2 berikut ini : 
Tabel 2. Distribusi Pembudidaya Berdasarkan Interaksi Komunikasi Dengan Penyuluh Perikanan

\begin{tabular}{|c|c|c|}
\hline Frekuensi (kali) & Jumlah & Persentase \\
\hline Rendah ( 1 kali ) & 23 & 46 \\
\hline Sedang ( 2 kali ) & 11 & 22 \\
\hline Tinggi ( > 3 kali ) & 16 & 32 \\
\hline Total & 50 & 100 \\
\hline
\end{tabular}

Sumber : Hasil penelitian Tahun 2012

Keterangan : - Frekuensi komunikasi minimum 1 kali

- Frekuensi komunikasi maksimum 4 kali

- $\quad$ Rata rata 2 kali

Tabel 2, menunjukkan bahwa sebagian besar pembudidaya jarang berhubungan langsung dengan penyuluh perikanan, namun melihat komposisi pilihan responden yang tidak terpaut jauh, disimpulkan bahwa pembudidaya ikan melakukan komunikasi dengan penyuluh perikanan walaupun tidak seluruhnya mengakses dalam waktu yang bersamaan.

\section{Peran Penyuluh Dalam Melakukan Komunikasi dengan Kelompok}

\section{Mardikanto}

berpendapat bahwa peran penyuluh tidak hanya terbatas menyampaikan inovasi dan mempengaruhi proses pengambilan keputusan oleh sasaran penyuluhan, akan tetapi seorang penyuluh harus mampu menjadi jembatan penghubung antara pemerintah atau lembaga penyuluhan yang diwakilinya dengan masyarakat sasaran, baik dalam hal menyampaikan inovasi atau kebijakan yang harus diterima dan dilaksanakan oleh masyarakat sasaran, maupun untuk menyampaikan umpan balik atau tanggapan masyarakat kepada pemerintah atau lembaga penyuluhan yang bersangkutan. Sehubungan dengan pendapat ini maka peran penyuluh dalam penelitian ini adalah sampai sejauh mana penyuluh memberikan bimbingan dan penyuluhan mengenai kegiatankegiatan budidaya maupun kegiatan minapolitan. Dari hasil penelitian terlihat bahwa intensitas penyuluh berinteraksi dengan pembudidaya cenderung lebih jarang di sisi lain secara simultan selalu mengawal dan memberikan arahan, responden menyampaikan pendapatnya bahwa penyuluh perikanan mempunyai peranan dalam memajukan dan mempertahankan eksistensi usaha budidaya mereka.

Ada empat kriteria yang dijadikan ukuran untuk melihat peran penyuluh sejalan dengan pendapat Van Den Ban dan Hawkins (1999) dan Mardikanto (1993), yaitu : a) Memberikan bimbingan dan berperan aktif memajukan kelompok, 
b) Membantu peningkatan teknologi budidaya kelompok, c). Materi penyuluhan sesuai dengan usaha budidaya dan permasalahan kelompok, dan d) Membantu perkembangan dan kemajuan kelembagaan kelompok. Peran penyuluh dalam melakukan komunikasi dengan kelompok dikategorikan dalam kategori rendah, sedang dan tinggi seperti tabel berikut

Tabel 3. Peran Penyuluh Perikanan Dalam Melakukan Komunikasi Kelompok

\begin{tabular}{|c|c|c|c|c|c|c|}
\hline \multirow{2}{*}{$\mathrm{No}$} & \multirow[t]{2}{*}{ Peran Penyuluh } & \multicolumn{2}{|c|}{ Skor } & \multirow[t]{2}{*}{ Kategori } & \multirow{2}{*}{$\begin{array}{c}\text { Jumlah } \\
\text { Resp. }\end{array}$} & \multirow{2}{*}{$\begin{array}{c}\text { Persen } \\
\text { Tase }\end{array}$} \\
\hline & & Min & Max & & & \\
\hline \multirow[t]{3}{*}{1.} & Memberikan bimbingan dan berperan & 6 & 11 & Rendah (skor,6-7) & 29 & 58 \\
\hline & aktif memajukan kelompok & & & Sedang (skor,8-9) & 12 & 24 \\
\hline & & & & Tinggi (skor, 10- & 9 & 18 \\
\hline \multirow[t]{3}{*}{2.} & Membantu peningkatan teknologi & 4 & 9 & Rendah (skor,4-5) & 17 & 34 \\
\hline & budidaya kelompok & & & Sedang (skor,6-7) & 23 & 46 \\
\hline & & & & Tinggi (skor,8-9) & 10 & 20 \\
\hline \multirow[t]{3}{*}{3.} & Materi penyuluhan sesuai dengan usaha & 3 & 8 & Rendah (skor,3-4) & 8 & 16 \\
\hline & budidaya dan permasalahan kelompok & & & Sedang (skor,5-6) & 40 & 80 \\
\hline & & & & Tinggi (skor,7-8) & 2 & 4 \\
\hline \multirow{3}{*}{4.} & Membantu perkembangan dan kemajuan & 3 & 9 & Rendah (skor,3-4) & 17 & 34 \\
\hline & kelembagaan kelompok & & & Sedang (skor5-7) & 26 & 52 \\
\hline & & & & Tinggi (skor,8-9) & 7 & 14 \\
\hline
\end{tabular}

Sumber : Hasil penelitian Tahun 2012

Berdasarkan tabel 3, dapat disimpulkan bahwa mayoritas responden memilih kategori rendah untuk peran penyuluh kriteria pertama. Kriteria kedua menunjukkan mayoritas responden memilih kategori sedang. Kriteria ketiga peran penyuluh dalam jejaring komunikasi kelompok mayoritas responden memilih kategori sedang. Sedangkan kriteria keempat peran penyuluh dalam jejaring komunikasi kelompok mayoritas responden memilih kategori sedang.

\section{Indikator Perkembangan Bantuan} Minapolitan di Kecamatan Ciseeng. Menurut Maringi (2009), dalam penelitiannya mengenai pembangunan pedesaan berkelanjutan melalui pendekatan kawasan minapolitan yang dilakukan di Kabupaten Boyolali, menyimpulkan bahwa faktor kunci keberhasilan pengelolaan kawasan minapolitan berdasarkan pendekatan MDS (Multidimensional Scaling) dengan analisis Rapfish yang digunakan untuk mengetahui keberlanjutan pembangunan wilayah secara multidisipliner, dimana dimensinya menyangkut berbagai aspek serta memiliki atribut atau indikator yang terkait dengan keberlanjutan kawasan tersebut adalah : 1) Teknologi budidaya ikan lele, 2) ketersediaan instalasi pengolahan limbah (IPAL), 3) Permintaan ikan lele, 4) Tingkat pendidikan rata-rata masyarakat 
pembudidaya dan, 5) Standarisasi mutu produk. Merujuk kepada beberapa kriteria atribut yang merupakan indikator perkembangan program bantuan minapolitan di kawasan ini maka ditetapkan beberapa ukuran sebagai indikator perkembangan yaitu 1). Bertambahnya volume/ jumlah produksi ikan lele, 2). Meningkatnya kemampuan teknis pembudidaya ikan lele, 3). Meningkatnya minat usaha pembudidaya ikan lele serta, 4). Bertambahnya jaringan pemasaran pembudidaya ikan lele.

Dari keempat indikator tersebut disimpulkan bahwa ada keterkaitan yang erat antara kemampuan pembudidaya dalam mengakses media dan sumber informasi maupun peran penyuluh dalam melakukan pembimbingan di lapangan.

Dari hasil analisis terbukti bahwa akses media dan sumber informasi pembudidaya berpengaruh signifikan terhadap indikator perkembangan program bantuan minapolitan kriteria pertama yaitu bertambahnya volume / jumlah produksi ikan lele.

Dari hasil uji Pearson Chi Square terbukti bahwa intensitas komunikasi dengan penyuluh berpengaruh signifikan terhadap indikator perkembangan program bantuan minapolitan kriteria pertama, kedua, ketiga, serta ke empat. Selanjutnya Peran Penyuluh Perikanan terhadap Indikator Perkembangan Program Bantuan Minapolitan dibagi menjadi 4 kriteria yaitu : a)
Memberikan bimbingan dan berperan aktif memajukan kelompok, b) Membantu peningkatan teknologi budidaya kelompok, c). Materi penyuluhan sesuai dengan usaha budidaya dan permasalahan kelompok, dan d) Membantu perkembangan dan kemajuan kelembagaan kelompok.

Dari hasil uji Pearson Chi Square terbukti bahwa peran penyuluh (memberikan bimbingan rutin dan berperan aktif menggerakkan dan memajukan kelompok) berpengaruh signifikan terhadap keempat indikator perkembangan minapolitan.

Dari hasil uji Pearson Chi Square di atas terbukti bahwa peran penyuluh (membantu peningkatan teknologi budidaya kelompok) berpengaruh signifikan terhadap indikator perkembangan program bantuan minapolitan kriteria pertama, kedua dan keempat.

Dari hasil uji Pearson Chi Square terbukti bahwa peran penyuluh (materi penyuluhan sesuai dengan usaha budidaya dan permasalahan kelompok) berpengaruh signifikan terhadap indikator perkembangan program bantuan minapolitan kriteri ketiga.

Dari hasil uji Pearson Chi Square terbukti bahwa peran penyuluh (membantu perkembangan dan kemajuan kelembagaan kelompok) berpengaruh signifikan terhadap indikator perkembangan program bantuan minapolitan kriteria kedua dengan kriteria keempat.

Pembahasan Hasil Analisis

Karakteristik individu terdiri dari faktor internal individu yang 
sangat menentukan kebutuhannya sehingga mampu mengerahkan kekuatan sesuai dengan tuntutan pribadi seseorang, sedangkan karakteristik eksternal individu berkaitan dengan situasi baik perkembangan, perubahan maupun pertumbuhan yang dipengaruhi oleh situasi luar individu tersebut dan dapat mempengaruhi eksistensi dan kemampuan individu (Sulistiyani dan Rosidah, 2003). Karakteristik individu pembudidaya yang dibahas dalam penelitian ini adalah karakteristik internal pembudidaya dalam mengakses media dan sumber informasi.

Hasil dari penelitian ini menunjukkan bahwa dari responden keseluruhan ternyata presentase sering tidaknya pembudidaya mengakses media dan sumber informasi seperti televisi, radio, koran, majalah dan sejenisnya dalam satu periode pemeliharaan cukup berimbang antara kategori jarang (mengakses $<2$ kali) yaitu sebesar 30 persen, kategori sedang (mengakses 2-3 kali) sebesar 34 persen dan kategori sering (mengakses $>4$ kali) sebesar 36 persen. Hal ini mengandung arti bahwa rata-rata pembudidaya melakukan akses terhadap media cetak maupun elektronik walaupun dengan frekuensi yang berbeda-beda, dan yang terpenting proses ini akan dapat mempengaruhi pembudidaya dalam memperbaiki kekurangankekurangan pengelolaan usaha budidayanya baik dari segi teknis maupun manajemen produksi.

\section{Komunikasi Kelompok dengan Penyuluh Perikanan}

Karakteristik

komunikasi

kelompok dalam penelitian ini menyajikan data tentang peran penyuluh perikanan dengan mengukur banyaknya kelompok berkomunikasi dengan penyuluh yang diukur dengan mengelompokkannya dalam 3 kategori yaitu rendah, sedang dan tinggi. Data hasil penelitian mengenai peran penyuluh perikanan ternyata yang paling dominan adalah peran penyuluh kriteria ketiga yaitu materi penyuluhan sesuai dengan usaha budidaya dan permasalahan kelompok yang masuk ke dalam kategori sedang dengan nilai skor tertinggi sebesar 40 persen bila dibandingkan dengan ketiga kriteria peran penyuluh lainnya.

Peran penyuluh perikanan dalam penelitian ini menunjukkan hasil bahwa penyuluh perikanan dalam menyampaikan bimbingannya kepada kelompok pembudidaya telah sesuai dengan programa penyuluhan yang dibuatnya yang antara lain memuat mengenai ketepatan materi yang disuluhkan kepada pembudidaya, demikian juga dengan permasalahan-permasalahan

kelompok mengenai teknis maupun administrasi.

\section{Indikator Perkembangan Program}

\section{Bantuan Minapolitan}

Indikator perkembangan bantuan program minapolitan merupakan variabel yang dijadikan ukuran sampai sejauhmana keberhasilan program minapolitan di 
kawasan minapolitan Kecamatan Ciseeng. Dari hasil analisis uji Pearson Chi Square digambarkan lebih lanjut bahwa apabila indikator perkembangan program bantuan minapolitan di Kecamatan Ciseeng dihubungkan dengan karakteristik pembudidaya dalam mengakses media dan sumber informasi menunjukkan bahwa : 1) sering tidaknya pembudidaya mengakses media dan sumber informasi berkorelasi positif atau berhubungan signifikan pada taraf kepercayaan $\sigma$ 0,05 dengan indikator perkembangan program bantuan minapolitan yang pertama yaitu bertambahnya volume / jumlah produksi ikan lele dengan PValue sebesar 9.528, dan probabilitas sebesar 0.049, dengan yaitu meningkatnya minat usaha pembuudidaya ikan lele dengan nilai P-Value sebesar 10.492 dan nilai probabilitas sebesar 0.033 .

Hubungan intensitas komunikasi yang terjalin antara pembudidaya dengan penyuluh perikanan dengan keempat indikator perkembangan program bantuan minapolitan, dari hasil uji Pierson Chi Square menunjukkan bahwa hubungan tersebut berkorelasi positif atau berhubungan signifikan pada taraf kepercayaan $\sigma 0,05$ dengan indikator perkembangan program bantuan minapolitan yang pertama, kedua, ketiga dan keempat.

Hubungan antara peran penyuluh perikanan kriteria pertama yaitu memberikan bimbingan rutin dan berperan aktif menggerakkan dan memajukan kelompok dengan keempat indikator perkembangan program bantuan minapolitan, dari hasil uji Pierson Chi Square menunjukkan bahwa peran penyuluh perikanan kriteria pertama yaitu memberikan bimbingan rutin dan berperan aktif menggerakkan dan memajukan kelompok tersebut berkorelasi positif atau berhubungan signifikan pada taraf kepercayaan $\sigma$ 0,05 dengan indikator perkembangan program bantuan minapolitan yang pertama, kedua, ketiga dan keempat.

Hubungan antara peran penyuluh perikanan kriteria kedua yaitu membantu peningkatan teknologi budidaya kelompok dengan keempat indikator perkembangan program bantuan minapolitan, dari hasil uji Pierson Chi Square menunjukkan bahwa peran penyuluh perikanan kriteria kedua yaitu membantu peningkatan teknologi budidaya kelompok tersebut berkorelasi positif atau berhubungan signifikan pada taraf kepercayaan $\sigma 0,05$ dengan indikator perkembangan program bantuan minapolitan yang pertama, kedua, serta keempat.

Hubungan antara peran penyuluh perikanan kriteria ketiga yaitu materi penyuluhan sesuai dengan usaha budidaya dan permasalahan kelompok dengan keempat indikator perkembangan program bantuan minapolitan, dari hasil uji Pierson Chi Square menunjukkan bahwa peran penyuluh perikanan kriteria ketiga yaitu materi penyuluhan sesuai dengan usaha budidaya dan permasalahan kelompok tersebut berkorelasi positif atau berhubungan signifikan pada taraf 
kepercayaan $\sigma 0,05$ dengan indikator perkembangan program bantuan minapolitan yang ketiga.

Hubungan antara peran penyuluh perikanan kriteria keempat yaitu membantu perkembangan dan kemajuan kelembagaan kelompok dengan keempat indikator perkembangan program bantuan minapolitan, dari hasil uji Pierson Chi Square menunjukkan bahwa peran penyuluh perikanan kriteria keempat yaitu membantu perkembangan dan kemajuan kelembagaan kelompok tersebut berkorelasi positif atau berhubungan signifikan pada taraf kepercayaan $\sigma 0,05$ dengan indikator perkembangan program bantuan minapolitan yang kedua dan keempat.

\section{KESIMPULAN}

1. Hasil hipotesis membuktikan bahwa karakteristik individu pembudidaya ikan dalam mengakses media informasi dan Peran Penyuluh Perikanan berhubungan nyata dengan Perkembangan program minapolitan.

2. Dari hasil analisis uji Pearson Chi Square dengan taraf kepercayaan $\alpha=0,05$ menunjukkan bahwa karakteristik individu pembudidaya dalam mengakses media dan sumber informasi berhubungan nyata dengan bertambahnya volume/jumlah produksi ikan lele (P-Value = 9.528; Probabilitas $=0.049$ ) dan dengan meningkatnya minat usaha pembudidaya ikan lele $(\mathrm{P}-$ Value $=$ 10.492; Probabilitas $=0.033)$.
3. Hasil penelitian dan uji Pearson Chi Square mengenai intensitas komunikasi pembudidaya ikan dengan penyuluh perikanan terjalin dengan frekuensi rata-rata 2 kali. Berhubungan nyata dengan bertambahnya volume/jumlah produksi ikan lele $(\mathrm{P}-$ Value $=21.286$; Probabilitas $=$ 0.000 ), dengan meningkatnya kemampuan teknis pembudidaya $(\mathrm{P}-$ Value $=16.850 ;$ Probabilitas $=$ 0.002), dengan meningkatnya minat usaha pembudidaya (PValue $=17.034 ;$ Probabilitas $=$ 0.002), dan dengan bertambahnya jaringan pemasaran pembudidaya $(\mathrm{P}-$ Value $=10.594 ;$ Probabilitas $=$ 0.032).

4. Dari hasil analisis uji Pearson Chi Square dengan taraf kepercayaan $\alpha=0,05$ menunjukkan bahwa peran penyuluh :

a. Pertama, yaitu memberikan bimbingan rutin dan berperan aktif menggerakkan dan memajukan kelompok berpengaruh nyata terhadap bertambahnya volume/jumlah produksi ikan lele $(\mathrm{P}-\mathrm{Value}=$ 18.733; Probabilitas $=0.001)$, dengan meningkatnya kemampuan teknis pembudidaya (P-Value = 16.844; Probabilitas $=0.002$ ), dengan bertambahnya minat usaha pembudidaya $(\mathrm{P}-$ Value $=$ 10.163; Probabilitas $=0.038$ ), dan dengan bertambahnya jaringan pemasaran pembudidaya (P-Value = 13.26; Probabilitas $=0.010$ ). 
b. Kedua, yaitu membantu peningkatan teknologi budidaya kelompok berhubungan nyata dengan bertambahnya volume produksi ikan lele $(\mathrm{P}-$ Value $=$ 14.511; Probabilitas $=0.006$ ), dengan meningkatnya kemampuan teknis pembudidaya (P-Value = 19.238; Probabilitas $=0.001$ ), dan dengan bertambahnya jaringan pemasaran pembudidaya (P-Value = 28.203; Probabilitas $=0.000$ ).

c. Ketiga, yaitu materi penyuluhan sesuai dengan usaha budidaya dan permasalahan kelompok berhubungan nyata dengan meningkatnya minat usaha pembudidaya (P-Value = 11.577; Probabilitas $=0.021$ ) .

d. Keempat, yaitu membantu perkembangan dan kemajuan kelembagaan kelompok berhubungan nyata dengan meningkatnya kemampuan teknis pembudidaya ikan lele (P-Value $=11.273$; Probabilitas $=0.024)$ dan dengan bertambahnya jaringan pemasaran pembudidaya ikan lele (P-Value - 15.721; Probabilitas $=0.003)$.

\section{DAFTAR PUSTAKA}

Akbar. Ali (2005). Menggunakan SPSS Bagi Peneliti Pemula. Penerbit M2S. Bandung.

Arikunto., Suharsimi. Ny. (2006). Prosedur Penelitian. Suatu Pendekatan Praktek, Jakarta. Edisi Revisi, Penerbit Rineka Cipta.

Dinas Peternakan dan Perikanan Kabupaten Bogor. Buku Rencana Induk Pengembangan Kawasan Minapolitan. Bogor. 2010.

Dinas Peternakan dan Perikanan Kabupaten Bogor. Surat Keputusan Bupati Bogor tentang Pembentukan Pokja Pengembangan Kawasan Minapolitan di Kabupaten Bogor. Nomor. 523/220/Kpts/Huk/2010 Tanggal 20 April 2010. Bogor.

Dinas Peternakan dan Perikanan Kabupaten Bogor. Surat Keputusan Bupati Bogor tentang Penetapan Lokasi Pengembangan Kawasan Minapolitan di Kabupaten Bogor. Nomor. $523.31 / 227 / \mathrm{Kpts} / \mathrm{Huk} / 2010$

Tanggal 26 April 2011. Bogor.

Dinas Peternakan dan Perikanan Kabupaten Bogor. Surat Keputusan Bupati Bogor tentang Penunjukkan Lokasi Sentra Minapolitan (Minapolis) di Kabupaten Bogor. Nomor. 523/197/Kpts/Per-UU/2011 Tanggal 21 April 2011. Bogor.

Keputusan Menteri Kelautan dan Perikanan Nomor 39/MEN/2011 perubahan Keputusan Menteri Kelautan dan Perikanan Nomor 32/MEN/2010 tentang Penetapan Kawasan Minapolitan Seluruh Indonesia. http://www.kkp.go.id. 
Diakses pada tanggal 04 Maret 2012.

Keputusan Menteri Kelautan dan Perikanan Nomor 12/MEN/2010 tentang Minapolitan. http://www.kkp.go.id. Diakses pada tanggal 04 Maret 2012.

Keputusan Menteri Kelautan dan Perikanan Nomor 18/MEN/2011 tentang Pedoman Pelaksanaan Minapolitan. http://www.kkp.go.id. Diakses pada tanggal 04 Maret 2012

McQuail D. (1991). Teori Komunikasi Masa Suatu Pengantar. Jakarta. Erlangga.

Mardikanto. T. (1993). Penyuluhan Pembangunan Pertanian. Sebelas Maret. University Press. Surakarta.

Maringi. A. (2009). Pembangunan Perdesaan Berkelanjutan Melalui Pendekatan Pengembangan Kawasan Minapolitan di Kabupaten Boyolali. Tesis Sekolah Pascasarjana Institut Pertanian Bogor. Bogor.

Sekretariat Jenderal. (2010). Rencana Strategis Kementerian Kelautan dan Perikanan 2010-2014. Jakarta : Sekretariat Jenderal, Kementerian Kelautan dan Perikanan.
Sulistiyani Ambar. T dan Rosidah. 2003. Manajemen Sumberdaya manusia. Yogyakarta. Penerbit Graha Ilmu. Sophia. S. (1988). Informasi Hasil Penelitian yang Diperlukan oleh penyuluh Pertanian Jawa Barat. Hubungan dengan Karakteristik Penyuluh sebagai Pengguna Informasi. Tesis Sekolah Pascasarjana Institut Pertanian Bogor. Bogor.

Singarimbun. M., dan S. Effendi. (1989). Metode Penelitian Survai. Jakarta. LP3ES.

Susanto-Sunario, Astrid.S. (1993). Globalisasi dan Komunikasi. Jakarta: Pustaka Sinar Harapan.

Sugiyono, 2004. Metode Penelitian Administrasi. Alfabeta. Bandung.

Santoso, Singgih. (2001). SPSS Versi Mengolah Data Statistik Secara Profesional. PT. Elex Media Komputindo, Jakarta.

Umar. H. (2001). Metode Penelitian untuk Skripsi dan Tesis Bisnis. Jakarta. PT. Raja Grafindo Persada.

Van Den Ban dan H.S. Hawkins. (1999). Penyuluhan Pertanian. Jogyakarta. Penerbit Kanisius. 